\title{
Perancangan Sistem Informasi Berbasis Komputer untuk Manajemen Perawatan Fasilitas Industri Manufaktur Kapal
}

\author{
Ulil A. Fida Husain, Sri Rejeki Wahyu Pribadi, Mohammad Sholikhan Arif. \\ Jurusan Teknik Perkapalan, Fakultas Teknologi Kelautan, Institut Teknologi Sepuluh Nopember (ITS) \\ Jl. Arief Rahman Hakim, Surabaya 60111 Indonesia \\ e-mail:sri-rejeki@na.its.ac.id
}

\begin{abstract}
Abstrak-Beberapa galangan setingkat denganPT. Dok dan Perkapalan Surabaya masih menggunakans istem manual dalam melakukan kegiatan manajeman perawatan peralatan / mesin. Hal ini menyebabkan keterlambatan tindakan perawatan mesin dikarenakan kurangnya informasi dan tidak adanya system peringatan yang mendukung manajemen perawatan. Itu semua menyebabkan keterlambatan perawatan yang berakibat pada menurunya umur mesin. Oleh karena itu perlu adanya suatu pelatihan ketrampilan mengenai tindakantindakan awal perawatan peralatan / mesin kepada operator mesin produksi menggunakan metode Total Productive Maintenance (TPM). Tujuan dari tugas akhir ini adalah untuk merancang system informasi manajemen perawatan fasilitas industry manufaktur kapal. Model system ini dapat memberikan informasi perawatan peralatan / mesin dan system peringatan jadwal perawatan. Pertama dilakukan analisa kondisi existing mengenai system informasi perawatan. Kedua dilakukan penentuan parameter-parameter dan pengumpulan data-data informasi perawatan. Ketiga merancang system informasi manajemen perawatan menggunakan program visual basic. Pembuatan model system ini menggunakan system perancangan database dengan parameter metode TPM. Berdasarkan hasil perancangan system dan uji validasi serta verifikasi program yang dirancang, didapatkan terjadi perubahan efektifitas dalam hal alur penyampaian informasi perawatan, system penyimpanan informasi perawatan, dan kemudahan akses dalam mendapatkan informasi perawatan. Sistem yang dirancang dapat memperbaiki sistem manual yang diterapkan. Sistem informasi manajemen perawatan peralatan / mesin dapat memenuhi semua kebutuhan yang dibutuhkan oleh supervisor, karyawan dan operator mesinproduksi.
\end{abstract}

Kata kunci-Sistem informasi manajemen, Total Productive Maintenance (TPM), preventive maintenance, database system, prototype

\section{PENDAHULUAN}

$\mathrm{D}$ ITENGAH ketidakstabilan perekonomian di sector maritim serta semakin tajamnya persaingan di dunia industri manufaktur serta permintaan pembuatan alat transportasi laut yang melonjak secara signifikan, maka merupakan suatu keharusan bagi setiap perusahaan untuk lebih mengefektifkan dan mengefisiensi setiap kegiatan operasionalnya. Perkembangan teknologi akhir-akhir ini berjalan dengan pesat dan jalur informasi dituntut untuk lebih cepat. Hal ini dapat dirasakan diberbagai kegiatan dan dibidang industri manufaktur. Efek domino yang ditimbulkan dari perkembangan teknologi adalah semakin banyaknya permintaan kebutuhan produksi, semakin tinggi pula penggunaan teknologi canggih berupa mesin dan fasilitas galangan produksi lainya. Dan ini menyebabkan kebutuhan akan fungsi perawatan akan semakin bertambah besar dan ketat supaya hasil dari produksi sesuai dengan kebutuhan.

Dalam usaha untuk dapat terus menggunakan fasilatas produksi agar kontinuitas produksi dapat terjamin dan terjaga, maka direncanakan kegiatan perawatan yang dapat menunjang umur suatu mesin dan fasilitas produksi. Umur mesin serta perawatan secara rutin suatu mesin dapat dijadikan standar kelancaran dari sebuah hasil dan proses produksi. Program perawatan mesin dapat membantu memperkirakan suatu komponen mesin untuk dapat bekerja sesuai dengan tujuan yang diinginkan dalam periode tertentu.

Selain perawatan fasilitas yang perlu diberikan perhatian, perlu adanya juga pengawasan. Walaupun metode perawatan sudah diterapkan dan terstruktur serta terjadwal dengan baik, perlu juga adanya sistem pengawasan. Yaitu sistem informasi manajemen (SIM) perawatan berbasis komputer dan terintegrasi langsung dengan penjadwalan pemeliharan fasilitas-fasilitas industri manufaktur kapal.

Pada kebanyakan industri manufaktur kapal, pada sistem pengawasan perawatan masih menggunakan sistem manual. Dimana pengawasan dilakukan dengan menggunakan sitem Kartu Kebutuhan Pemelihaaraan kertas konvensional. Kertas ini akan bergerak dari satu pekerjaan ke pekerjaan lain yang membutuhkan banyak waktu. Dalam skala jumlah besar risiko kesalahan karena human error menjadi lebih besar. Sistem ini kurang terintegrasi secara langsung dengan antar departemen yang mengurusi bagian perawatan peralatan. Sehingga perlunya konsep terbaharukan untuk mengatasi permasalahan ini. Oleh karena itu pengiriman data transfer menggunakan teknologi informasi untuk mendukung proses penyimpanan dan pencarian data yang lebih cepat, menyeluruh, dan efisien.

Prosedur yang terintegrasi dengan sistem ini menggunakan data base sistem dalam proses pengaturan, pemilihan, pengelompokan, dan operasi data untuk membuat sebuah laporan yang sistematis.

\section{URAIAN PENELITIAN}

\section{A. Konsep Dasar Perawatan (Maintenance)}

Pada dasarnya tidak ada peralatan manusia yang sempurna dan tidak dapat rusak. Karena itulah perlu adanya sistem perawatan. Sistem yang terintegrasi dari satu tempat ke tempat lain menggunakan teknologi guna mempersingkat waktu dan mengurangi kelemahan human error. Karena semakin berkembangnya teknologi semakin cepat pula tunntutan untuk hasil produksi. 
Semakin bertambahnya waktu semakin menurun pula kualitas yang dihasilkan oleh mesin. Dengan memberikan perawatan secara berkala diusahakan dapat mengembalikan performasi mesin secara normal. Meskipun pada akhirnya menurun melampaui batas toleransi dan diperbaiki kembali. Maka perlu adanya perawatan mesin secara preventive. Hal ini dapat terjadi secara berulang-ulang sampai pada batas dimana efektifitas mesin sudah tidak dapat lagi beroperasi secara maksimal dan melewati batas toleransi yang diijinkan.

Pada perusahaan-perusahaan kategori menengah kebawah, maintenance masih kurang diperhatikan. Karena kegiatannya cukup kompleks dan bukan hanya dilakukan sekali waktu saja. Hasil dari maintenance tidak dapat dirasakan secara langsung saat melakukan perawatan. Namun hasilnya dapat dirasakan pada masa yang akan datang. Apabila maintenance tidak dilakukan, maka secara teratur mesin-mesin akan mengalami kerusakan. Dan akhirnya akan berakibat fatal sehingga akan merugikan perusahaan. Dampak yang akan dirasakan adalah berkurangnya umur ekonomis mesin serta tingkat penyusutan yang tinggi.

Maintenance adalah suatu kegiatan memelihara atau menjaga fasilitas atau peralatan pabrik dan mengadakan perbaikan atau penyesuaian penggantian yang diperlukan agar terdapat suatu keadaan operasi yang memuaskan sesuai dengan yang direncanakan [1]. Hal ini supaya perusahaan dapat bekerja secara efisien dengan mencegah kemacetan atau bahkan mesin yang mati mendadak.

\section{B. Total Productive Maintenance (TPM)}

Total Productive Maintenance (TPM) adalah program perawatan yang melibatkan semua pihak yang terdapat dalam suatu perusahaan untuk dapat saling bekerja sama dalam menghilangkan break down machine, mengurangi waktu down time, memaksimalkan utilitas, kegiatan produksi serta kualitas dari produk yang dihasilkan. TPM juga merupakan suatu sistem perawatan yang preventive untuk memaksimalkan kecanggihan peralatan yang mana meliputi semua departemen dan fungsi organisasi. Sistem ini di perkenalkan oleh Jepang oleh Seichi Nakajima yang dikembangkan dari Preventive Maintenance system yang dianut oleh Negara USA. Total Productive Maintenance (TPM) merupakan suatu sistem perawatan pada mesin atau peralatan yang melibatkan semua divisi dan karyawan mulai dari operator hingga manajemen puncak berdasarkan komitmen yang telah disepakati bersama. Konsep Total Productive Maintenance (TPM) pertama kali diterapkan di Jepang pada tahun 1971. Pada awalnya Jepang belajar pemeliharaan produktifitas dari Amerika lalu digabungkan dengan kebudayaan Jepang yang kental dengan sistem kerja tim. TPM merupakan pencapaian efisiensi pemeliharaan mandiri melalui satu sistem yang lengkap berdasarkan keikutsertaan seluruh karyawan. Selain itu TPM merupakan gabungan dari beberapa ilmu tingkah laku (manusia dan mesin), rekayasa sistem, ekologi (perubahan mesin), dan logistic

TPM dirancang untuk mencegah terjadinya suatu kerugian karena terhentinya aktivitas produksi yang disebabkan oleh kegagalan fungsi dari suatu peralatan (mesin). Kerugian yang disebabkan oleh hilangnya kecepatan produksi mesin yang diakibatkan oleh kegagalan fungsi suatu komponen tertentu dari suatu mesin produksi dan kerugian karena cacat yang disebabkan oleh kegagalan fungsi komponen atau mesin produksi. Jadi dapat disimpulkan secara sederhana bahwa tujuan dari diaplikasikannya TPM adalah untuk mengoptimalkan efisiensi sistem produksi secara keseluruhan melalui aktivitas pemeliharaan dan perbaikan secara terorganisir. [2]

\section{TPM Sebagai Metode Perawatan}

Kecenderungan yang paling sering terjadi dilingkup maintenance pada perusahaan adalah perawatan dilakukan ketika hanya terjadi kerusakan. Mesin akan diperbaiki ketika terjadi kerusakan yang tentunya akan sering terjadi dikarenakan tidak adanya pencegahan secara preventive. Seringkali operator mengabaikan pertanda awal dari potensi kerusakan. Operator-pun tidak memiliki kompetensi dalam pemeliharaan mesin yang mereka operasikan setiap hari. Jika demikian, tentu kerusakan akan sering terjadi karena tidak adanya perawatan minor yang rutin, yang mungkin disebabkan oleh staf maintenance yang terlalu sibuk. Pemahaman operator akan dasar-dasar perawatan mesin akan sangat membantu dalam hal ini.

Dengan TPM, operator diharapkan mampu menangani masalah umum yang sering terjadi, misalnya mesin kotor, mur dan baut hilang, oli jarang diganti, kebocoran, bunyibunyi tidak normal, getaran berlebihan, filter kotor, dan sebagainya. Prinsip TPM menekankan peran operator yang harus mampu melakukan perawatan dan perbaikan ringan apabila muncul masalah pada mesin, sehingga masalahmasalah kecil pada mesin dapat segera diatasi tanpa harus menunggu kerusakan tersebut menjadi kompleks.

\section{Preventive Maintenance}

Disebut juga tindakan pencegahan atau overhaul. Yaitu kegiatan perawatan dan perawatan utnuk mencegah kerusakan tak terduga dan menemukan kondisi atau keadaan yang mnyebabkan fasilitas produksi lebih tepat. Dapat diartikan juga sebagai pekerjaan perawatan yang bertujuan untuk mencegah terjadinya kerusakan, atau cara perawatan yang direncanakan untuk pencegahan (preventif).[3] Pada gambar.1 menjelaskanken tentang pembentuk utama dari sebuah

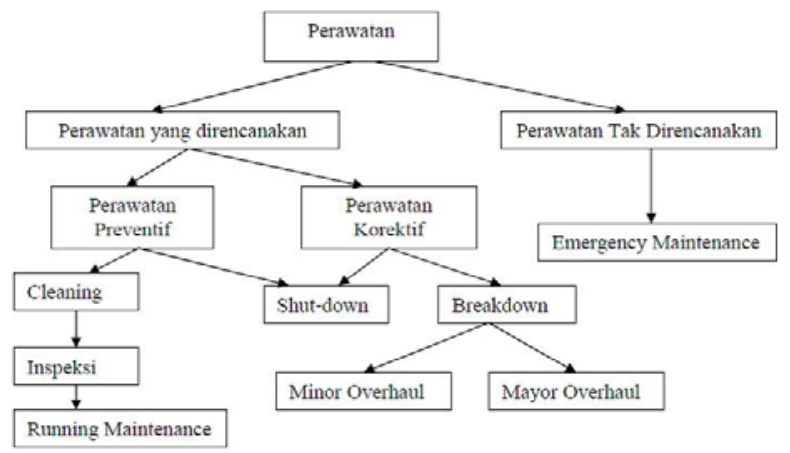

Gambar.1 Jenis-jenis metode perawatan berdasarkan waktu pelaksanaanya

sistem perawatan dengan berdasarkan watu dan kondisi mesin.

\section{E. Sistem Informasi manajemen}

Sistem informasi manajemen atau SIM (bahasa Inggris: management information sistem, MIS) adalah sistem perencanaan bagian dari pengendalian internal suatu bisnis yang meliputi pemanfaatan manusia, dokumen, teknologi, 
dan prosedur oleh eksistensi manajemen untuk memecahkan masalah bisnis seperti biaya produk, layanan, atau suatu strategi bisnis. Sistem informasi manajemen dibedakan dengan sistem informasi biasa karena SIM digunakan untuk menganalisis sistem informasi lain yang diterapkan pada aktivitas operasional organisasi. Secara akademis, istilah ini umumnya digunakan untuk merujuk pada kelompok metode manajemen informasi yang bertalian dengan otomasi atau dukungan terhadap pengambilan keputusan manusia, misalnya sistem pendukung keputusan, sistem pakar, dan sistem informasi eksekutif.

Sistem Informasi Manajemen merupakan sebuah bidang yang mulai berkembang sejak tahun 1960an. Walaupun tidak terdapat konsensus tunggal, secara umum Sistem Informasi Manajemen didefinisikan sebagai sistem yang menyediakan informasi yang digunakan untuk mendukung operasi, manajemen, serta pengambilan keputusan sebuah organisasi. Sistem Informasi Manajemen juga dikenal dengan ungkapan lainnya seperti: "Sistem Informasi”, "Sistem Pemrosesan Informasi”, "Sistem Informasi dan Pengambil Keputusan”. Sistem Informasi Manajemen menggambarkan suatu unit atau badan yang khusus bertugas untuk mengumpulkan berita dan memprosesnya menjadi informasi untuk keperluan manajerial organisasi dengan memakai prinsip sistem. Dikatakan memakai prinsip sistem karena berita yang tersebar dalam berbagai bentuk dikumpulkan, disimpan serta diolah dan diproses oleh satu badan yang kemudian dirumuskan menjadi suatu informasi.

Top level management dengan executive management dapat terdiri dari direktur utama (president), direktur (visepresident) dan eksekutif lainnya di fungsi-fungsi pemasaran, pembelian, teknik, produksi, keuangan dan akuntansi. Sedang middle level management dapat terdiri dari manajermanajer devisi dan manajer-manajer cabang. Lower level management disebut degan operating management dapat meliputi mandor dan pengawas.

Top level management disebut juga dengan strategic level, middle level management dengan tactical level dan lower management dengan tehcnical level.

\section{HASIL DAN DISKUSI}

\section{A. Sistem Informasi Perencanaan Penjadwalan}

PerawatanAgar breakdown kualitas dan kuantitas hasil yang dikeluarkan mesin dapat ditekan sekecil mungkin. Diperlukan suatu sistem perencanaan yang efektif dan efisien. Perusahaan menggunakan sistem perawatan preventive maintenance, dimana perawatan dilakukan secara rutin dan terjadwal untuk menanggulangi kerusakan mesin yang dapat membuat shutdown. Siklus perawatanya dilakukan secara teratur seperti setiap mingguan, bulanan, tahunan atau pada waktu-waktu khusus. Pada perusahaan ini menerapkan siklus rencana perawatan peralatan dilakukan setiap 3 bulan sekali. Pertimbangan memilih siklus perawatan setiap 3 bulan sekali berupa variable biaya perawatan yang sangat besar dan variable kemampuan dasar tenaga kerja operator mesin perihal pengetahuan kondisi mesin dan rasa memiliki terhadap mesin.

Penyususnan program bulanan dan tahunan dalam hal perawatan adalah strategi perusahaan yang terapkan. Untuk menentukan saat-saat dimana proses produksi sedang tinggi, untuk menyelaraskan jadwal libur, dan pemeriksaan keseluruhan. Data yang dipakai dalam penyusunan program perawatan adalah pengalaman sebelumnya, riwayat alat atau mesin, dan dari manual machine's guide book.

Departemen FASHAR dalam pembuatan jadwal perencanaan perawatan peralatan harus saling berkordinasi dengan departemen lainya. Karena proses perawatan dan perbaikan memerlukan waktu bahkan jika diperlukan mesin harus di shutdown. Jika mesin berhenti beroperasi dan tidak ada kordinasi dengan departemen lain, maka proses produksi yang sedang berlangsung akan mengalami gangguan. Dibawah ini adalah contoh dari jadwal rencana pemeriksaan alat-alat.

\section{B. Sistem Informasi Pelaksanaan Perawatan}

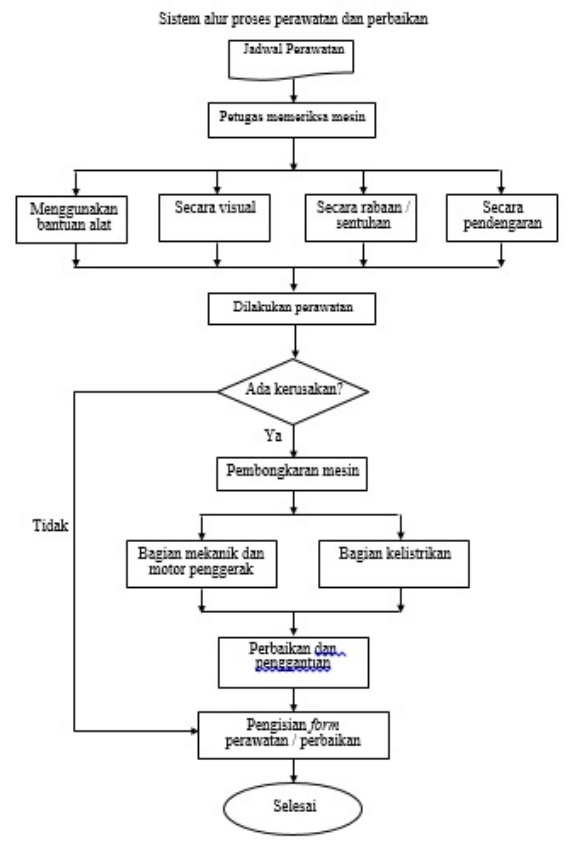

Gambar. 2 Diagram alur perawatan dan perbaikan

Sistem pelaksanan perawatan yang diterapkan perusahaan menggunakan historical data untuk menentukan siklus penjadwalan perawatan. Pada data-data sebelumnya penjadwalan perawatan tidak mengalami permasalahn, maka data tersebut akan tetap digunakan sebagai acuan penjadwalan. Penjadwalan akan dilakukan setiap minggu pertama pada bulan yang direncanakan. Mesin-mesin yang dilakukan perawatan dikelompokan ke dalam bengkel dimana mesin berada. Pada minggu dimana mesin dilakukan perawatan, bagian departemen perawatan yang bertangung jawab atas mesin-mesin yang ada dibengkel melakukan proses perawatan. Petugas perawatan akan melaksanakan kegiatan perawatan sesuai dengan SOP yang dimiliki perusahaan. Semua rencana kegiatan yang tertuang dalam program perawatan bulanan dimonitor pelaksanaanya menggunakan form. Sehingga akan diperoleh data-data pelaksanaan yang dapat digunakan untuk masukan pembuatan jadwal yang lebih efisien untuk kedepanya.

Proses pelaksanaan perawatan dilaksanakan pada waktu jam istirahat, waktu hari libur atau pada saat mesin tidak sedang beroperasi. Yang terpenting adalah tidak menggangu keberlangsungan proses produksi yang sedang berjalan. Petugas akan mengecek bagian mekanik dan bagian kelestrikan. Contoh jika dilihat secara visual, gerigi pada motor pengerak sudah aus maka akan dilakukan penggantian sesuai prosedur. Proses perawatan akan 
melibatkan keahlian petugas sesuai dengan jam terbang dan pengalamannya. Petugas akan mengecek menggunakan peralatan dan semua panca indra yang dimilikinya mulai dari secara visual, rabaan atau sentuhan dan suara.

\section{Sistem Penyimpanan Berkas Perawatan}

Proses penyimpanan berkas berupa Form, laporan perawatan, Surat Permintaan Repair (SPR) disimpan pada satu tempat di Departemen FASHAR. Semua informasi yang berupa berkas fisik disimpan menjadi satu arsip dan diletakan didalam almari. Untuk mengakses informasi yang berhubungan dengan perawatan peralatan / mesin harus menunggu ijin dari kepala departemen. Hal ini menjadikan informasi tidak mudah untuk diakses oleh supervisor dan karyawan perawatan karena informasi berkumpul pada satu tempat dengan sistem akses personal satu orang. Sistem pencarian data perawatan peralatan / mesin masih menggunakan sistem manual dan tidak terorganisir dengan baik.

\section{Sistem Implementasi Manajemen Perawatan}

Hasil observasi di galangan PT. Dok dan Perkapalan Surabaya sistem perawatan peralatan /mesin yang digunakan adalah sistem preventive maintenance. Sistem ini dirancang setiap tahun untuk mensinergikan anatara perawatan peralatan /mesin dengan proses produksi di galangan. Karena kegiatan perawatan peralatan /mesin tidak berdiri sendiri dalam prosesnya maka dalam pembuatanya harus diajukan perencanaan penjadwalanya ke dalam rapat besar perusahaan. Di dalam rapat harus menghadirkan kepala-kepala bagian departemen dan bengkel fungsinya untuk menentukan jadwal perawatan dan jadwal produksi supaya tidak terjadi waktu tunggu mesin dan waktu terbuang bagi proses produksi

\section{E. Analisis Hasil Sistem Perawatan Yang Berada di Galangan}

Dari hasil observasi di galangan PT. Dok dan Perkapalan Surabaya, didapatkan hasil olahan data yang menampilkan kondisi-kondisi mesin. Galangan memiliki jumlah bengkel 6 buah, jumlah mesin yang terdata 162 buah dan perbandingan jumlah mesin dengan kondisi baik : rusak adalah $82,1 \%$ : 19,9\%. Kondisi mesin yang terdapat di setiap bengkel-bengkel galangan masih terdapat mesin yang rusak atau mesin yang perlu penanganan perawatan lebih. Karena adanya kondisi mesin yang rusak walapun hanya tercatat $19.9 \%$, dapat mengakibatkan proses produksi terganggu dan memaksa bagian manager perencanaan untuk membuat jadwal produksi baru. Kondisi manajemen seperti ini sangatlah kurang efektif dan efisien dalam penerapanya di dunai produksi.

Sistem informasi manajemen perawatan yang diterapkan galangan masih belum efektif dan efisien, hal ini di tandai dengan masih adanya mesin yang rusak dan mengakibatkan time losses. Banyak hal yang menyebabkan mesin mengalami kerusakan. Penyebab-penyebab tersebut dapat terjadi karena kurang fahamnya operator mesin tentang kondisi mesin, teknisi mekanin yang menganggap enteng perawatan hingga bagian top level manajerial yang kurang memperhatikan sistem penjadwalan mesin. Melalui analisis menggunakan metode fish bone diagram akan diketahui dan dijabarkan penyebab-penyebab kegagalan sistem perawatan yang berakibat pada rusaknya mesin.
Diagram sebab akibat dengan metode fish bone diagram (diagram tulang ikan) dapat mempresentasikan penyebab terkecil dari sebuah permasalahan. Dalam pembuatan diagram di atas peneliti mengambil kasus kerusakan peralatan atau mesin yang berada di bengkel-bengkel proses fabrikasi. Dalam satu bulan proses produksi, tercatat kerusakan mesin yang terjadi mencapai 18\%. Kerusakan mesin dapat menyebabkan performasi mesin menurun dan berimbas pada hasil produksi yang akan menurun.

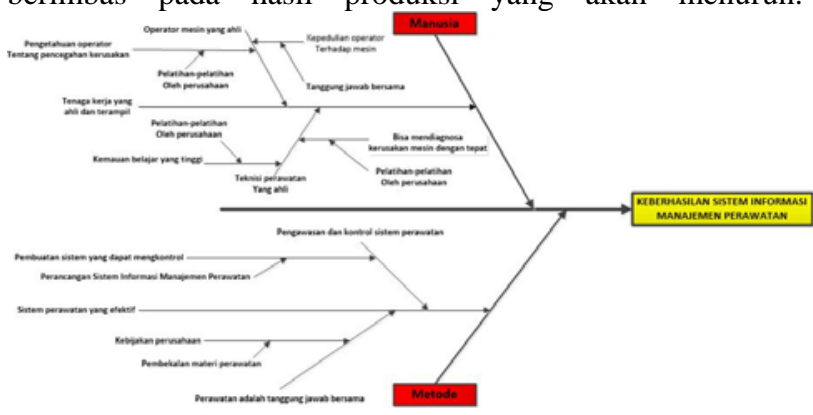

Gambar. 3 fish bone diagram

Dalam gambar.3 diagram tulang ikan ditetapkan bahwa masalah utama kerusakan mesin yang terjadi dikarenakan kegagalan sistem perawatan yang di terapkan galangan kurang maksimal. Untuk mengetahui pemecahan permasalahan yang terjadi maka perlu di uraikan lagi penyebab-penyebab masalah utama.

\section{F. Implementasi TPM Sebagai Sistem Perawatan}

Secara mendasar metode TPM sebagai sistem perawatan lebih menitik beratkan ke dalam mindset semua orang yang ada di perusahan, mulai dari top level (manager) samapai down level (operator mesin) bahwa perawatan mesin adalah tanggung jawab bersama. [4]

Kegiatan perawatan peralatan /mesin yang akan diterapkan dengan melibatkan operator mesin produksi, yang diberikan pelatihan-pelatihan tentang tata cara pengoperasian mesin yang benar dan tatacara perawatan mesin. Kegiatan selanjutnya adalah dengan membentuk aktifitas kelompok kecil (AKK). AKK ini dibentuk dengan tujuan untuk meningkatkan kerjasama tim, kemampuan dan pengetahuan individu tentang kondisi peralatan kerja dan juga untuk meningkatkan efektifitas dan produktifitas kerja.

Kegiatan yang melibatkan operator ini terdiri dari pelatihan-pelatihan yang diberikan kepada setiap operator mesin yang meliputi pengetahuan tentang karakteristik mesin-mesin produksi. Supaya operator mempunyai penegtahuan dasar dan pengetahuan tambahan tentang bagaimana mesin bekerja serta bagaimana menentukan gejala-gejala kerusakan. Dari pelatihan ini, setiap operator bertanggung jawab atas pelaksanaan perawatan pada mesin yang dioperasikannya. Untuk itu perlu adanya pelatihan standar bagi para operator mesin produksi.

Langkah-langkah perawatan yang akan dilakukan oleh operator mesin produksi yaitu pembersihan awal sekitar mesin, tindakan cepat pada sumber awal masalah, standarisasi pembersihan, pelumasan dan inspeksi menyeluruh.

Kegiatan perawatan oleh operator dapat memberikan kontribusi yang berarti dalam mendayagunakan mesin dan peralatan. Inti dari perawatan peralatan / mesin oleh operator adalah pencegahan (preventive) awal dari memburuknya kondisi peralatan. Hal ini dapat dilakukan dengan cara pengoperasian peralatan secara baik dan benar, 
memelihara kondisi peralatan / mesin, penyetelan yang baik dan benar, mencatat data kerusakan dan berbagai gangguan awal yang terjadi.

AKK dibentuk dengan tujuan untuk meningkatkan kemampuan dan pengetahuan individual tentang kondisi peralatn /mesin kerja dan juga utuk meningkatkan efektifitas dan produktifitas kerja. Para pelaksana perawatan harus berpedoman pada jadwal aktifitas yang telah dibuat yang meliputi waktu pelaksanaan, tim yang bertugas, SOP dan prosedur perawatan dan uraian komponen-komponen yang harus diperiksa sesuai dengan buku pertunjuk dan pedoman perawatan peralatan /mesin

\section{G. Perancangan Sistem Informasi Manajemn}

Dari hasil teori dan analisa menggunakan metode penyusunan database, maka dibuatkan suatu metode rancangan sistem informasi baru sebagai langkah perbaikan. Kerangka ini disusun untuk mencapai pemahaman dan penyususnan konsep perancangan program. Selanjutnya untuk membangun sistem informasi, maka diperlukan pengembangan kerangka dadar. Kerangka dadar perancangan sistem dapat dilihat pada gambar di bawah:

\section{H. Data Flow Diagram (DFD)}

Dari Entity Relation Diagram dapat diambil alur perjalanan data dan hubungan dengan user sebagai pengendali data. Untuk menggambarkan logika dari kebutuhan-kebutuhan sistem yaitu proses-proses apa saja yang dibutuhkan oleh sistem dan bagaimana keluar masuknya informasi dalam sistem digunakan Data Flow Diagram (DFD).

\section{Validasi Prototype}

Uji validasi bertujuan untuk menguji apakah sistem yang dirancang dapat berfungsi sepenuhnya dan memenuhi kebutuhan user sebagai sistem informasi manajemenperawatan mesin pada perusahaan.

Berdasarkan hasil uji validasi, prototype sistem informasi manajemen perawatan peralatan / mesin sudah daopat memenuhi kebutuhan user yaitu administrator, supervisor perawatan dan karyawan perawatan. prototype sistem informasi ,anajemen perawatan peralatan / mesin dapat memberikan laporan yang dibutuhkan supervisor dan melakukan control terhadap tindakan perawatan mesin yang mengalami keterlambatan penangannan dengan memberikan warning. Kebutuhan administrator dalam mengelola datadata sistem informasi manajemen perawatan peralatan / mesin sudah terpenuhi dengan adanya sistem penyimpanan di database, yang mengintegrasikan seluruh data dan mengolah data sehingga dapat menyajikan informasi berupa laporan data keseluruhan. Sedangkan untuk karyawan perawatan prototyope sistem informasi manajemen perawatan peralatan /mesin sudah memenuhi kebutuhan yang diperlukan karyawan yaitu karyawan mendapatkan informasi jadwal peralatan setiap harinya, letak mesin yang harus dilakukan perawatan, warning peralatan yang akan maupun belum dilakukan perawatan serta form SOP prosedural perawatan peralatan / mesin.

Pada Table.1 tiga pengguna user (Administrator, Supervisor perawatan dan Karyawan perawatan) mendapatkan hak akses sendiri-sendiri dan dan dapat memenuhi kebutuhanya masing-masing.

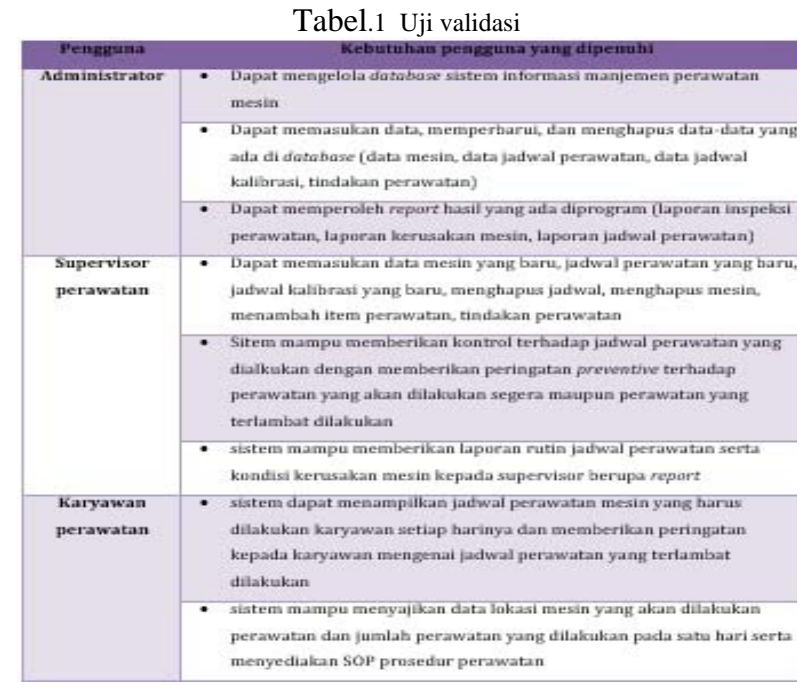

\section{J. Uji Protytpe}

Uji prototype bertujuan untuk mengetahui apakah prototype dapat mengatasi masalah dan kelemahan sistem perawatan peralatan / mesin yang lama. Pada uji ini sistem informasi manajemen perawatan mesin terbukti dapat mengatasi kelemahan sistem lama dengan perbandingan peforma seperti pada tabel di bawah.

Tabel.2 Uji prototype

\begin{tabular}{|c|c|}
\hline Sistem lama & Sistem baru \\
\hline $\begin{array}{l}\text { - Pengumpulan informasi data untuk } \\
\text { pelapuran sulit ditelusuri dan berlangsuag } \\
\text { bma }\end{array}$ & $\begin{array}{l}\text { - Data mudah ditelusuri kareaa suilah } \\
\text { terintegrasi sehingga waktu } \\
\text { pengumpulan data lebih cepat }\end{array}$ \\
\hline $\begin{array}{l}\text { - Sistem yang ada belum menyediakan } \\
\text { informasi tindalan harian perawatan, SOP } \\
\text { harian, SOP mingguan pada perawatan } \\
\text { yang dilakukan uleb karyawan perawatan }\end{array}$ & $\begin{array}{l}\text { - Sistem mesyediakan informasi } \\
\text { tindakanharian, SOP harian, SOP } \\
\text { mingguan dan prosedural perawatan } \\
\text { mesin yang harus dilakukan oleh } \\
\text { karyawan perawatan }\end{array}$ \\
\hline $\begin{array}{l}\text { - Sistem informast yang ada tidalc mudah } \\
\text { diakses oleh supervisor dan laryawan } \\
\text { perawatan karena informasi berkumpul } \\
\text { pada satu tempat dengan sistem akses } \\
\text { personal satu orang, sistem pencarian } \\
\text { masih manual dan tidak terorganisir } \\
\text { dengan baik }\end{array}$ & $\begin{array}{l}\text { - Sistem pencarian data dapat dialcses } \\
\text { kapan saja karena penyimpanan } \\
\text { menggunakan dutabasedan dengan } \\
\text { sistem akses non personal (lebilh dari } \\
\text { satu orang dengas hatasan yang ada) } \\
\text { serta sistem sudah terotumasi dan } \\
\text { ternoganisir dengan baik. }\end{array}$ \\
\hline $\begin{array}{l}\text { - Sistem yang lama belum bisa mengontrol } \\
\text { tindakan perawatan yang dilakukan oleh } \\
\text { laryawan }\end{array}$ & $\begin{array}{l}\text { - Sistem dapat memberikan warning } \\
\text { system, apalah perrencanaan jadwal } \\
\text { perawatan sudah dilakukan atau belum }\end{array}$ \\
\hline
\end{tabular}

Berdasarkan Tabel.2 dapat diketahui bahwa sistem informasi manajemen perawatan peralatan / mesin sudah dapat memperbaiki semua kelemahan sistem lama dari segi performance, information, control, efficiency dan service. Sistem informasi manjemen peralatan / mesin dapat melakukan pencarian data yang sudah terotomasi dengan cepat karena semua data mesin, data invetaris bengkel, semua jadwal, SOP sudah terintegrasi ke dalam satu penyimpanan menggunakan sistem database. Dengan adanya database, data-data yang ada di departemen perawatan (FASHAR) dapat terorganisir dengan baik, rapid dan terstruktur. Data juga dapat di update secara actual untuk mempercepat penyampaian informasi. 


\section{KESIMPULAN}

a. Sistem Informasi Manajemen yang diterapkan beberapa perusahaan saat ini masih menggunakan sistem informasi yang manual. Dimana sistem ini masih terdapat beberapa kekurangan-kekurangan yang dapat menyumbang permasalahan dalam keterlambatan proses produksi. Yaitu sistem masih menggunakan berkas fisik saja dalam menyampaikan perintah dan informasi perawatan peralatan / mesin berupa SPR (Surat Permintaan Reparasi). Sistem penyampaian informasi harus melewati kepala departemen lalu supervisor dengan berurutan begitu juga sebaliknya dalam penyampaiaan pelaporan perawatan.

b. Dalam merancang sistem informasi manajemen berbasis komputer perlu menentukan parameter-parameter dalam pembuatannya. Parameter-parameter ini berupa data informasi apa saja yang akan ditampilkan. Data-data tersebut berupa data jadwal perawatan, data jadwal kalibrasi, data spesifikasi mesin, invetaris mesin yang ada di beberapa bengkel, standar operasional harian dan mingguan, prosedur dalam kegiatan perawatan dan surat permintaan perawatan. Data-data tersebut akan di integrasikan untuk memudahkan pengguna dalam memberi dan menyampaikan informasi berkaitan dengan perawatan peralatan / mesin.

c. Dalam mengimplementasikan sistem informasi manajemen perawatan adalah dengan cara merancangan sistem informasi yang berbasis komputer dengan metode database system. Sistem ini diberi nama Sistem Informasi Manajemen-Perawatan (SIM-P). Sistem informasi manajemen ini dibuat menggunakan alat bantu Visual Studio. Dengan Inputan dat informasi manajemen perawatan. lalu akan di proses oleh sistem sesuai dengan permintaan user. Dan hasil output berupa laporanlaporan kegiatan yang berhubungan dengan perawatan mesin / peralatan. Sistem ini dapat memberikan informasi, kontrol kegiatan perawatan, sistem warning jadwal perawatan dan laporan-laporan yang berkaitan dengan kegiatan perawatan. Sistem ini dirancang dengan tiga user (pengguna). Supervisor, administrator dan karyawan (teknisi dan operator mesin). 3 pengguna ini memiliki hak akses yang berbeda sesuai dengan jabatannya masing-masing.

\section{UCAPAN TERIMA KASIH}

Penulis mengucapakan terima kasih kepada Jurusan Teknik Perkapalan Surabaya, Fakultas Teknologi Kelautan, Institut Teknologi Sepuluh Nopember atas fasilitas-fasilitas yang diberikan untuk menunjang penelitian seperti Laboratorium Pusat Bisnis Maritim dan Laboratorium Produksi serta ucapan terima kasih penulis kepada PT. DPS atas data-data untuk kelengkapan tugas akhir.

\section{DAFTAR PUSTAKA}

[1] Naibaho, (1985). Konsep Dasar Perawatan Peralatan. New York.

[2] Rosa, Yasmendra. (2011). Perencanaan dan Penerapan Preventive Maintenance Peralatan Laboratorium, Staf Pengajar Jurusan Teknik Mesin Peliteknik negeri Padang, Padang.

[3] Davis, Roy, K. (1995). Productivity Improvement Through TPM. The Manufacturing Pracitioner Series, Prentice Hall, New York.

[4] Sudrajat, Ating, (20016). Pelaksanaan Total Productive Maintenance Pada Skala Perusahaan Industri. Bogor. 